\title{
Rural Citizens' Perceptions on Microfinance Services Adoption in Tanzania: Moderating Effects of Demographic Factors
}

\author{
Julius J. Macha \\ Institute of Finance Management, Faculty of Accounting, Banking and Finance, Tanzania \\ E-mail: koroma85@yahoo.com
}

Type of the Paper: Research Paper.

Type of Review: Peer Reviewed.

Indexed in: OpenAIRE.

DOI: http://dx.doi.org/10.5281/zenodo.1041993.

Google Scholar Citation: IJMTS

\section{How to Cite this Paper:}

Macha, Julius J. (2017). Rural Citizens' Perceptions on Microfinance Services Adoption in Tanzania: Moderating Effects of Demographic Factors. International Journal of Management, Technology, and Social Sciences (IJMTS), 2(2), 70-83.

DOI: http://dx.doi.org/10.5281/zenodo.1041993.

International Journal of Management, Technology, and Social Sciences (IJMTS)

A Refereed International Journal of Srinivas University, India.

(C) With Authors.

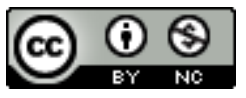

This work is licensed under a Creative Commons Attribution-Non Commercial 4.0 International License subject to proper citation to the publication source of the work.

Disclaimer: The scholarly papers as reviewed and published by the Srinivas Publications (S.P.), India are the views and opinions of their respective authors and are not the views or opinions of the SP. The SP disclaims of any harm or loss caused due to the published content to any party. 


\title{
Rural Citizens' Perceptions on Microfinance Services Adoption in Tanzania: Moderating Effects of Demographic Factors
}

\author{
Julius J. Macha \\ Institute of Finance Management, Faculty of Accounting, Banking and Finance, Tanzania \\ E-mail: koroma85@yahoo.com
}

\begin{abstract}
The purpose of this study is to investigate the moderating effects of demographic variables among the rural citizens in Tanzania on the association between perceived benefits and determinants of intention to adopt microfinance services by using the Theory of Reasoned Action. Stratified and multistage sampling techniques were employed to select respondents and survey questionnaire was administered to collect the data that resulted in a response rate of $82 \%$. The structural equation modelling (SEM) was employed to analyse the hypotheses of the core and moderating models. The study's findings demonstrated that gender and education moderate the impact of perceived benefits and subjective norms on the rural citizens' intention to adopt microfinance services. In addition, the findings suggest that perceived benefits, attitude and subjective norms significantly influence rural citizens' intention to adopt microfinance services. The current study offers useful suggestions to policy makers to design relevant policies customised according to the strength of the demographic variables that influence determinants of rural citizens' intention to adopt microfinance services.
\end{abstract}

Keywords: Microfinance, Moderating effects, Perceived benefits, Attitude, Subjective norms, Demographic variables, Behavioral Intention.

\section{INTRODUCTION :}

Microfinance is a special financial services that aims to help people who are excluded by the mainstream financial sector. Most of the restructured or private conventional banks targeted mainly on institutions and individuals who could meet the bank requirements such as documentations, formal collateral and other banking requirements (Rubambey, 2005). Microfinance services have been widely used in many developing countries to reduce the nation's poverty rate (Okibo \& Makanga, 2014)by helping the poor individuals to accumulate more assets, reduce vulnerability to various uncertainties and improve their incomes through the following schemes: micro-credit, savings, money transfer, micro-insurance, and payment services.
Tanzanian government has been promoting microfinance services aggressively from mid1990sas an alternative means for majority of unbanked Tanzanians, especially the rural citizens (70.9\%) (National Bureau of Statistics, 2013).In Tanzania, most of the people live in rural areas where they engage in agricultural sector, therefore the availability of microfinance services could assist the rural farmers to increase their agricultural production by employing modern farming methods (Mbawuni \& Nimako, 2015; Zohir \& Matin, 2004).

Despite of diverse government efforts to encourage low income individuals to adopt the microfinance services, the response given by rural citizens is still unwelcome. The low usage of financial services could be the result of a number of issues that include lack of basic financial knowledge, inadequate understanding 
of the benefits of microfinance services, fear of the negative repercussions of borrowings and negative recommendations from the community members (Bank of Tanzania, 2014; Chogo \& Sedoyeka, 2015; FSDT, 2014). Thus, the study to address the behavioral issues that affect rural citizens' intention to adopt microfinance services is essential for private and public sectors to design their apposite strategies and policies that encourage usage of microfinance services.

Nevertheless, rural citizens with different demographic characteristics have been behaving differently towards the issues mentioned above.

For example, the largest proportion of microfinance borrowers in Tanzania are women compared to men who are mainly served by commercial banks (Alliance for Financial Inclusion, 2016). Furthermore, large number of women lack tertiary education that limit them from being in the formal employment, hence rely on microfinance as the source of funds for establishing micro and small businesses.

In many behavioural studies that are related to intention to perform online shopping and real estate purchase; and adoption of technology, herbal products, and mobile payment; demographic variables could play a significant moderating role (AL-Nahdi \& Bakar, 2015; Gibler \& Nelson, 2003; Ismail, Sanuri, \& Mokhtar, 2015; Park, Yang, \& Lehto, 2007; Taluka \& Masele, 2017; Venkatesh, Morris, Davis, \& Davis, 2003). However, the studies that investigate the moderating effects of demographic variables on the relationships between perceived benefits, attitude, subjective norms, and intention to adopt microfinance services among rural farmers in Tanzania are limited. Therefore, the objective of this study is to investigate the moderating effects of demographic factors (gender and education) in the context of microfinance in Tanzania.

\section{THEORETICAL FRAMEWORK AND HYPOTHESES DEVELOPMENT :}

Theory of reasoned action (TRA) explains that behavioural intention is the main determinant of an individual actual behaviour and the intention is influenced by the investigated person's own attitude and other people's behaviour (termed as subjective norms) (Fishbein \& Ajzen, 1975). In the study context, rural farmers' adoption of microfinance would increase if the farmers' intention to adopt the service could be developed.TRA is suitable for this study because of its parsimony and predictive powers to explicitly account for behavioural intention.

Gender and education have been investigated across various research disciplines such as decision making processes, effects of education on job performance (Ng \& Feldman, 2009). The study conducted by Hooft, Born, Taris, \& Flier (2006) using the TRA framework found that job applicants attitude was strongly related to intention among men compared to women. In addition the social pressure was highly related to intention among women than men. This could possibly be due to men being more autonomous than women and in the other hand women being more relational than men in the study context. However, studies on the moderating effects generated by the respondents' demographic characteristics: gender and education on the relationship between TRA's constructs to influence rural citizens' intention to adopt microfinance services are less common.

In addition, most of the extant studies modified the TRA model through inclusion of other constructs to predict individual behavioural intention in different contexts (Ajzen, 1991; Davis, 1989; Otieno, Liyala, Odongo, \& Abeka, 2016; Simbolon, 2015). Therefore, this study modifies TRA model through inclusion of perceived benefits so as to address the problem facing rural citizens towards adoption of microfinance services more comprehensively. Past studies examined the impact of perceived benefits on individuals' intention to perform target behaviour such as entrepreneurship behaviours, computer security adoption, and mobile banking adoption, however limited studies used it in microfinance context (Chuah, Ting, de Run, \& Cheah, 2016; Claar \& Johnson, 2010; Shanmugam, Savarimuthu, \& Wen, 2014). Figure 1 illustrates the research model developed to address the issues of this study, where the independent constructs are perceived benefits, attitude and subjective norms. 
Behavioural intention in the model is the dependent construct and moderating variables are the demographic factors (gender and education). The next section discusses the hypotheses developed in this study based on the direct relationships (H1-H3) and the moderating effects (H4 and H5).

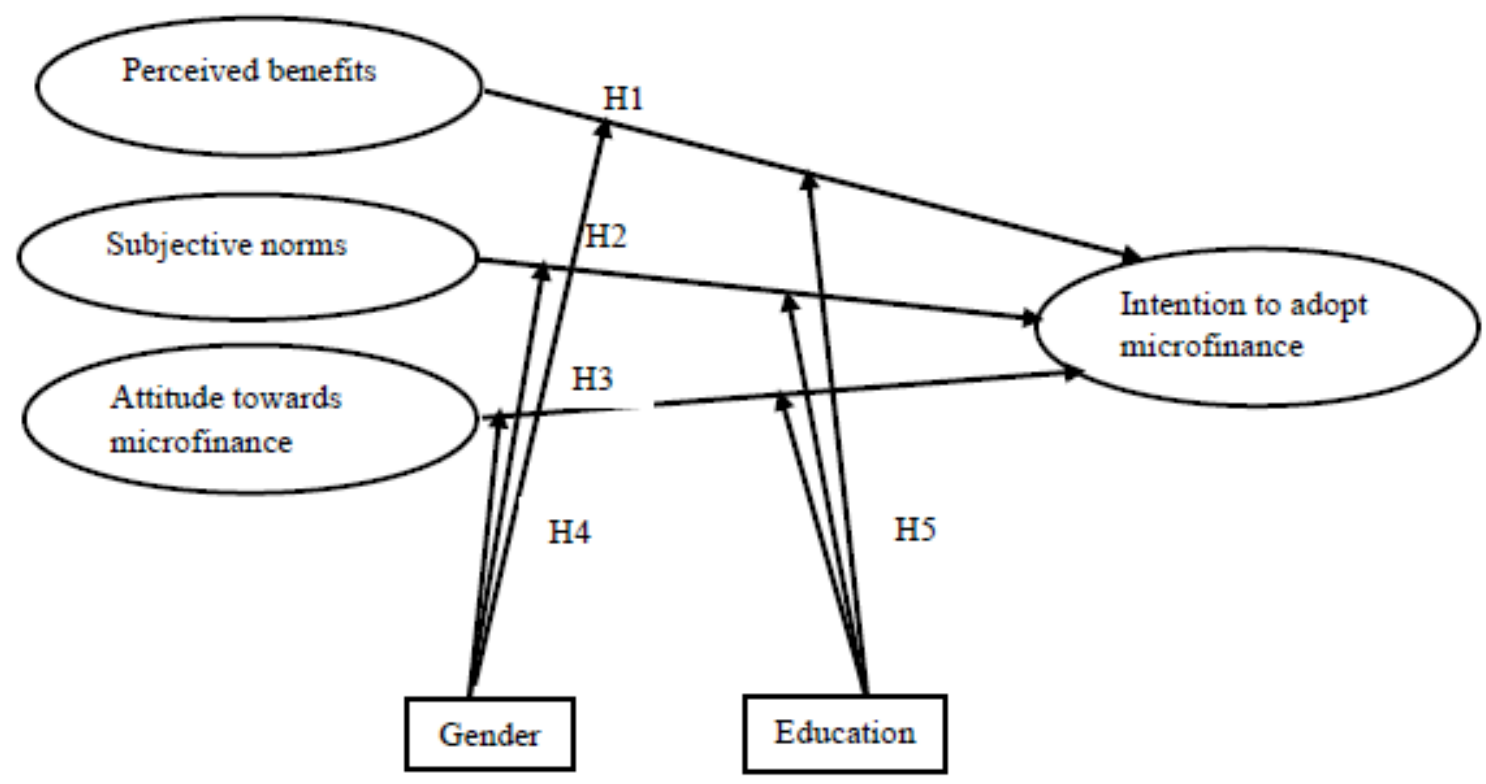

Figure 1: Research Framework Note: H4:a,b,c; H5:a,b,c

In the context of this study, perceived benefits reflect the possible favourable outcomes that could be generated as the result of an individual participation in microfinance services. An individual's intention to participate in various behaviours could be hampered with insufficient insight about the benefits of the target behaviour (Shanmugam et al., 2014). The association between perceived benefits and behavioural intention has been confirmed by various previous studies to be positive (Ross, Ross, Rahman, \& Cataldo, 2010; Tanadi, Samadi, \& Gharleghi, 2015). Based on that premise, this study predicts that:

H1: Perceived benefits have positive impact on rural citizens' intention to use microfinance services

Subjective norms refers to the degree that an individual think the referent group would approve or disapprove her decision to use microfinance services. An individual decision to perform particular behaviour could be influenced by social pressure from relatives, social groups or community members (Ajzen,
1991; Fishbein \& Ajzen, 1975). Alsmady, Rahman, and Muhammad (2014; Mishra (2014) confirmed that subjective norm has direct and positive impact on intention to perform a particular behaviour. The social pressure is generally stronger for individuals who lack experience about a certain behaviour, hence reliance on their most important others. Similarly, the social pressure could be strong among the rural citizens in Tanzania due to lack of necessary financial knowledge about microfinance and the strength of the prevailing collectivist culture as well. Therefore, this study hypothesizes that:

H2: subjective norms have positive effect on rural citizens' intention to adopt microfinance services

In this study, attitude refers to the degree that individual has positive evaluation about using microfinance services. This implies that, Individuals with strong favourable perception about engaging in a particular behaviour would have high likelihood to respond positively towards performance of the particular behaviour 
(Alqasa, 2014). The following studies indicate there is positive association between individual's attitude and behavioural intention to execute certain behaviours: Gopi and Ramayah (2007); Putit and Johan, (2015); Tsordia and Papadimitriou (2015). The unfavourable perception of rural citizens about microfinance could also affect their intention to use microfinance services. Therefore, the following hypothesis is proposed;

H3: Attitudes of rural citizens' have positive effect on intention to adopt microfinance services

Past studies indicate that perception of women and men towards certain behaviours are different(Chen, Yan, Fan, \& Gordon, 2015; Venkatesh et al., 2003). For instance Yang, Hsu, and Tan (2010) found that, the intention to use you tube was stronger for women than men. Females were more influenced by the usefulness of you tube and social norms, while interpersonal norms were strong for males. Similarly, the differences between women and men about the use of microfinance services could have influence on the factors that affect behavioural intention such as attitude and subjective norms. Other studies such as Wong, Teo, and Russo (2012) found gender had no effect on the determinants of behavioural intention for teachers to use computers. The possible reason could be the difference between men and women had been narrowed due to improved education about computer to both females and males. However, due to various economics and cultural constraints among women to access conventional banking services, the perception of women towards microfinance services could be higher compared to men. In that line, this study proposes that:

H4a: Gender moderates the relationship between perceived benefits and the rural citizens' intention to adopt microfinance services. Specifically, the effect of rural female on the relationship between perceived benefits and behavioral intention is stronger than that of males.

H4b: Gender moderates the relationship between subjective norms and the rural citizens' intention to adopt microfinance services. Specifically, the effect of rural female on the relationship between subjective norms and behavioral intention is stronger than that of males.

H4c: Gender moderates the relationship between attitude and the rural citizens' intention to adopt microfinance services. Specifically, the effect of rural female on the relationship between attitude and behavioral intention is stronger than that of males.

Education level influences individuals' perception about the participation in diverse behaviours (Gibler \& Nelson, 2003). This implies that the likelihood of more educated individuals to engage in a particular behaviour is higher than the least educated ones. This could be due to ability of high educated individuals to asses different issues related to the respective behaviour such as benefits and risks that enhances the confidence to perform the behaviour. The study of Abu-Shanab (2011) found that, individuals' level of education moderated the determinants of behavioral intention to use internet banking. As the rural citizens have different levels of education about microfinance services, there is a high possibility that education moderates the impact of attitude, perceived benefits and subjective norm on the intention to adopt microfinance services. Thus, this study proposes the following hypotheses:

H5a: Education moderates the relationship between perceived benefits and the rural citizens' intention to adopt microfinance services. Specifically, the effect of highly educated rural citizens on the relationship between perceived benefits and behavioral intention is stronger than that of less educated citizens.

H5b: Education moderates the relationship between subjective norms and the rural citizens' intention to adopt microfinance services. Specifically, the effect of highly educated rural citizens on the relationship between subjective norms and behavioral intention is stronger than that of less educated citizens.

H5c: Education moderates the relationship between attitude and the rural citizens' intention to adopt microfinance services. Specifically, the effect of highly educated rural citizens on the relationship between attitude and behavioral 
intention is stronger than that of less educated citizens.

\section{RESEARCH METHODS :}

\subsection{Measures}

The measurement items were adapted from relevant past studies and modified to match the context of this study without affecting the primary message of the items. A five point Likert scale that stretched from strongly disagree (1) to strongly agree (5) was employed to measure perception of each respondent about the items. The perceived benefits, was measured using five items adapted from Kim, Ferrin and Rao (2008); Jebarajakirthy and Lobo (2014); Lee (2009). The instrument also included five items on attitude, four items on subjective norms and three items on behavioural intention(Deng, Mo, \& Liu, 2013; Mbawuni \& Nimako, 2015; Nasri, 2011; Rouibah, Ramayah, \& May, 2011; Siddik, Sun, Yanjuan, \& Kabiraj, 2014; Wu, Li, $\& \mathrm{Fu}, 2011)$.

The research instrument had two sections in which the first part was about demographic profile of the respondents and the second one contained the constructs' measurement items. Banking and academic experts assessed the questionnaire for face and content validity that ensured the relevance of the measures in the respective study context. Thereafter, the questionnaire statements were translated in Swahili because majority of the rural citizens are more conversant with the national language than English. Prior administering the instrument for the main study, pre-test was carried out to improve the questionnaire that ensured respondents could provide accurate responses on the modified items.

\subsection{Sample and data collection}

The sample for this study was drawn from rural citizens in Tanzania who engage in farming activities that utilize an average of 0.9 to 3 hectares of land (Rugumamu, 2014). The study targeted rural citizens because they comprise the majority of the Tanzanian population. Furthermore, they engage in agricultural activities that contribute about $31 \%$ of the country's gross domestic product (GDP)and $30 \%$ of the export earnings (Ministry of
Agriculture Food Security and Cooperatives, 2015). Thus, improved agricultural productivity through usage of microfinance services would enhance the employment opportunities to majority and increased food security in the country. The participants of this study were nonusers of microfinance services, literate in Swahili or English, which are official languages in Tanzania and aged 18 years or more. Microfinance services involve contractual obligations such as loan contracts that cannot be entered by the minors, hence citizens of the majority age were considered in this study.

The survey based questionnaire was used to collect data from respondents in five zones: Coastal, northern, southern highland, lake zone and central zone that have the majority of farmers in Tanzania (National Bureau of Statistics, 2014). Drop off and pick up method was employed to distribute questionnaires to 600 respondents selected using probability sampling method. The drop off and pick up method was apposite in the rural areas where the existing infrastructure could impede the application of other methods such as mails or telephone surveys (Allred \& Ross-Davis, 2011). The method yielded 536 responses that included incomplete responses. As the result, 489 responses were suitable for analysis after deleting the incomplete responses.

\subsection{Data analysis}

The analysis involved descriptive and inferential statistics through Statistical Package for Social Sciences (SPSS) version 20.0 and Structural Equation Modelling through Analysis of Moment Structures (AMOS) version 21.0. This study adopted three steps of structural equation modelling to validate and test the proposed hypotheses. The measurement model was validated by using Confirmatory Factor Analysis (CFA) in the first stage. Thereafter, the structural model was examined to test the hypothesized relationships. Finally, to determine the moderating effects, multiple-group SEM analysis was carried out.

\section{RESULTS AND DISCUSSION :}

\subsection{Respondents' demographic profile}

The sample of respondents comprised of more 
women (59\%) relative to men $(41 \%)$ and most of the respondents (98\%) were aged 18 to 64 years. The results demonstrate that majority of the rural population were within the working age of 15 to 64 years(National Bureau of Statistics, 2014). The majority of the respondents (68\%) were married and 32\% were unmarried ones. The results indicate about $57 \%$ of the rural population had primary education, while $43 \%$ had secondary or higher education.

\subsection{Evaluation of Measurement model}

CFA was conducted prior modelling the constructs in the structural model to validate the measurement model through assessment of unidimensionality, validity and reliability of the constructs. Table 1 indicates that the goodness of fit of the initial measurement model was poor because most of the fit indices failed to achieve the acceptable threshold (Kline, 2011; Schumacker \& Loamx, 2010). Following that, the model fit was achieved through execution of three iterations which lead to elimination of three items (PBE4, PBE5, and BI3) that had factor loading lower than the acceptable values of 0.5 (Awang, 2015; Fornell \& Larcker, 1981). Therefore, the unidimensionality and model fitness were achieved after elimination of three items from the model as shown in table 1.

Table 1: Fitness indices of the measurement model.

\begin{tabular}{|l|l|l|l|l|l|l|}
\hline Particulars & GFI & SRMR & RMSEA & CFI & NNFI & Chi-square/df \\
\hline Initial model -index values & 0.917 & 0.042 & 0.082 & 0.916 & 0.892 & 4.298 \\
\hline Final model -index values & 0945 & 0.040 & 0.062 & 0.953 & 0.938 & 2.883 \\
\hline
\end{tabular}

Note: GFI: Goodness of fit index; SRMR: Standardized root mean square residual; CFI: comparative fit index; RMSEA: Root mean square of error approximation; NNFI: Non-normed fit index.

Table 2 indicates that the convergent validity is achieved because the scores of average variance extracted (AVE) attained the acceptable minimum values of 0.5 (Awang, 2015). In addition, the statistical results indicate that all items significantly loaded on their respective constructs and the standardized loadings ranged from 0.64 to 0.82 .Thus, the measurement items are correctly measuring the respective constructs. The discriminant validity was assessed as well to ensure the measures of one construct are distinct from measures of other construct. The diagonal value in table 2 (square root of AVE) for each construct is higher than the correlation between the given construct and others (Fornell \& Larcker, 1981). The results imply that discriminant validity among the constructs was acceptable. As the scores of composite reliability (CR) and AVE exceeded the minimum required of 0.7 and 0.5 respectively, the results confirm that, the respondents offered consistent answers about the studied measurement items (Bagozzi, Baumgartner, \& Yi, 1992).

Table 2: Constructs validity, reliability and discriminant validity.

\begin{tabular}{|l|l|l|l|l|l|l|}
\hline Construct & CR & AVE & PBE & Att & SN & BI \\
\hline Perceived benefits (PBE) & 0.791 & 0.559 & 0.747 & - & - & - \\
\hline Attitude (Att) & 0.868 & 0.569 & 0.219 & 0.755 & - & - \\
\hline Subjective norms (SN) & 0.802 & 0.505 & 0.333 & 0.025 & 0.710 & - \\
\hline Behavioural intention (BI) & 0.732 & 0.579 & 0.519 & 0.253 & 0.464 & 0.761 \\
\hline
\end{tabular}

Note: CR: Composite reliability; AVE: Average variance extracted.

4. 3 Hypotheses Testing

\subsubsection{The core model test}

The hypothesized relationships of the core model were tested by using structural equation modelling (SEM). The model demonstrated a good fit as evidenced by the following fit indices results that achieved the acceptable threshold: RMSEA $=0.062 ;$ GFI $=0.945 ;$ SRMR $=0.04$; 
NNFI $=0.938 ;$ CFI $=0.953$ and the score for chi-square to degree of freedom of 2.883. The results confirm the observed data fits well the theoretical model. The results of the hypotheses test indicate all coefficients estimate were significant for each examined path of the core model as shown in table 3.

Table 3: Results of hypothesis testing.

\begin{tabular}{|l|l|l|l|l|l|l|}
\hline Hypothesis & \multicolumn{2}{|l|}{ Structural Path } & $\begin{array}{l}\text { Estimate of standard } \\
\text { coefficient }\end{array}$ & $\begin{array}{l}\text { Critical } \\
\text { ratio (C.R) }\end{array}$ & Remarks \\
\hline H1 & PBE & $---->$ & BI & $0.371^{* * *}$ & 5.774 & Supported \\
\hline H2 & SN & $---->$ & BI & $0.336^{* * *}$ & 5.464 & Supported \\
\hline H3 & Att & $---->$ & BI & $0.163^{* * *}$ & 3.129 & Supported \\
\hline
\end{tabular}

Note : $\quad{ }^{* * *} \mathrm{p}<0.01$; Att: Attitude; SN: Subjective norms PBE: Perceived benefits; BI: Behavioural intention;

Table 3 indicates that perceived benefit has positive significant effect on the citizens' intention to adopt microfinance services $(\beta=0.371, p<0.01)$. Thus supporting hypothesis H1. The results suggest that, the enhanced perception of the benefits of microfinance services among the rural citizens would lead to increased intention to adopt microfinance services. The findings support past studies such as Shanmugam et al. (2014); and Tanadi et al. (2015) that suggest the higher the benefits earned from engaging in a behaviour, the stronger an individual intention to perform such behaviour.

The findings confirm citizens' intention to adopt microfinance services is significantly influenced by subjective norms $(\beta=0.336, p<0.01)$, that support hypothesis H2. The results are consistent with other previous studies which confirm the positive relationship between subjective norms and behavioural intention (Heikal \& Khaddafi, 2014; Putit \& Johan, 2015). The possible reason for the relationship could be because of the communal culture in Tanzania that friends, family or community members can influence the citizens to use microfinance services. In addition, the low level of education about financial services among the rural citizens could contribute for citizen's dependence on opinion of their influential counterparties.

The association between attitude and behavioural intention is statistically significant $(\beta=0.163, p<0.01)$. Hence hypothesis $\mathrm{H} 3$ is supported. These results are in line with other studies such as (Amin, Rahma, \& Razak, 2014; Ashraf, 2014; Sayid \& Echchabi, 2013). The findings suggest that, an increased positive perception about the usefulness of microfinance services would contribute to high likelihood of adopting microfinance among the rural citizens.

\subsubsection{Moderation effects}

The multi-group analysis SEM in Amos was used to test the moderation effects in which each moderating variable was categorised into two groups according to the nature of the variables. Education was split into primary and secondary or higher education; gender categorised as female and male. The moderation effects on the examined structural model is confirmed when the chi-square difference between the constrained and unconstrained model is significant (Maiyaki, 2013). In addition, each path is independently constrained and if the computed chi-square exceeds the chi-square threshold that demonstrates moderation effect to be significant along a particular path. Table 4 indicates the model fit results following introduction of each moderator in the structural model.

The model had three independent latent variables (attitude, subjective norms and perceived benefits) that influence the dependent variable (behavioral intention). Following the introduction of each moderator independently in the structural model the impact of attitude was insignificant at $\mathrm{p}>0.1$ in each session, hence was omitted from the model accordingly. Subsequently, the hypotheses $\mathrm{H} 4 \mathrm{c}$ and H5care not tested because they were predicted to moderate association between attitude and behavioral intention. The structural model results for each moderating variable (gender and 
education) demonstrate satisfactory model fit because all the model fit indices were within the required threshold (Table 4) (Awang, 2015;
Kline, 2011). The next section presents and discuss the result of the moderation hypotheses.

Table 4: Fitness indices of the structural model.

\begin{tabular}{|l|l|l|l|l|l|l|}
\hline Particulars & GFI & SRMR & RMSEA & CFI & NNFI & Chi-square/df \\
\hline Model -index values (Gender) & 0.954 & 0.042 & 0.047 & 0.962 & 0.943 & 2.087 \\
\hline $\begin{array}{l}\text { Model-index values } \\
\text { (Education) }\end{array}$ & 0.959 & 0.043 & 0.042 & 0.969 & 0.954 & 1.871 \\
\hline
\end{tabular}

Table 5 indicates the moderation effects and the respective path for each group examined in this study. As shown on table 5, the positive impact of subjective norms and perceived benefits on the citizens' behavioural intention to adopt microfinance services is significantly moderated by gender $(\Delta \chi 2=14.201$ at $\mathrm{p}<0.1)$. In addition, the results confirm that association between subjective norms and behavioural intention is stronger for female group $(\beta=0.213, p<0.01)$ compared to male group $(\beta=0.188, p<0.01)$. Thus hypothesis H4b was supported. Likewise, the moderation effect on the association between perceived benefits and behavioural intention was higher among the females $(\beta=0.338, p<0.01)$ than males $(\beta=0.305, p<0.01)$ that support hypothesis H4a. The findings confirm the social pressure is stronger among the females that imply women are more influenced by their friends or referent groups to use microfinance services. It is noted as well that women find more useful to adopt microfinance services possibly due to their diverse economic and cultural constraints to access financial services from the conventional banks.

Furthermore, the results show the relationship between subjective norms and perceived benefits on behavioural intention is significantly moderated by education as well $(\Delta \chi 2=15.705$ at $\mathrm{p}<0.05$ ). However, the positive effect between subjective norms on the behavioural intention was higher for citizens with secondary or higher education $(\beta=0.267, p<0.01)$ than citizens who had primary education $(\beta=0.157, p<0.01)$, which supported hypothesis H5b. Similarly, the association between perceived benefits and behavioural intention was greater for secondary or more educated citizens $(\beta=0.355, \mathrm{p}<0.01)$ compared to those with primary education $(\beta=0.258, p<0.01)$ that confirmed hypothesis H5a. The findings suggest that secondary or higher educated citizens' intention to adopt microfinance services would be high if the benefits associated with microfinance services are increased.

Table 5: Moderating Effects Results.

\begin{tabular}{|l|l|l|l|l|l|l|}
\hline Hypothesis & $\boldsymbol{\chi 2} \mathbf{( d / f )}$ & $\begin{array}{l}\boldsymbol{\chi 2} \\
\text { difference }\end{array}$ & $\begin{array}{l}\text { Regression } \\
\text { weights }\end{array}$ & $\begin{array}{l}\text { Regression } \\
\text { weights }\end{array}$ & $\mathbf{H}$ & Path \\
\hline Gender & & & Female & Male & - & - \\
\hline $\begin{array}{l}\text { Constrained } \\
\text { model }\end{array}$ & $114.391(56)$ & - & - & - & - & - \\
\hline $\begin{array}{l}\text { Unconstrained } \\
\text { model }\end{array}$ & $100.190(48)$ & $14.201^{*}$ & $\begin{array}{l}0.338 \\
0.213\end{array}$ & $\begin{array}{l}0.305 \\
0.188\end{array}$ & $\begin{array}{l}\text { H4a } \\
\text { H4b }\end{array}$ & $\begin{array}{l}\text { PBE } \rightarrow \text { BI } \\
\text { SN } \rightarrow \text { BI }\end{array}$ \\
\hline Education & $=$ & $=$ & Primary & $\begin{array}{l}\text { Higher } \\
\text { education }\end{array}$ & $=$ & $=$ \\
\hline $\begin{array}{l}\text { Constrained } \\
\text { model }\end{array}$ & $105.494(56)$ & $=$ & $=$ & $=$ & $=$ & $=$ \\
\hline
\end{tabular}


International Journal of Management, Technology, and Social

\begin{tabular}{|l|l|l|l|l|l|l|}
\hline $\begin{array}{l}\text { Unconstrained } \\
\text { model }\end{array}$ & $89.789(48)$ & $15.705 * *$ & 0.258 & 0.355 & H6a & PBE $\rightarrow$ BI \\
H6b & SN $\rightarrow$ BI \\
\hline
\end{tabular}

Note: $\mathrm{p}^{* * *}<0.01 ; \mathrm{p}^{* *}<0.05 ; \mathrm{p}^{*}<0.1$; ns: non-significant, H: Hypothesis; SN: subjective norms; PBE: perceived benefits; $\mathrm{BI}$ : behavioral intention

\section{CONCLUSION AND IMPLICATIONS :}

This study examined the moderation impact of demographic variables (gender and education) on the association between perceived benefits, TRA independent constructs on the intention to adopt microfinance services among the rural citizens. The findings confirmed gender and education significantly moderate the relationship between perceived benefits, subjective norms and behavioural intention. The findings imply that policy makers should take into account the demographic variable differences while developing and implementing various policies and strategies about microfinance.

The effect of subjective norms on behavioral intention is found stronger among the female and high educated citizens relative to male and less educated citizens respectively. Thus, policy makers should institute awareness campaigns that encourage the usage of microfinance services among the females and high educated citizens through their influential counterparties such as friends, spouses, family members or community leaders. In addition, the use of various social groups such self-help groups (SHG), rotating and saving associations (ROSCAs), cooperative societies and other village congregations to disseminate information about the usefulness of microfinance services among the rural citizens.

The study results confirm the impact of perceived benefits on intention is strong among the females and higher educated compared to male and less educated citizens respectively. This suggests that policy makers should promote the benefits of microfinance services among the females and high educated citizens through various communication channels such as social media, fliers, brochures, television, internet and short messages (SMS). Furthermore, the perceived benefits should be enhanced through introduction of more innovative products that match the demands of female and high educated citizens.
This study contributes to the body of knowledge through application of the theory of reasoned action (TRA) in the context of microfinance in the rural setting. Furthermore, the modification of TRA model by including the perceived benefits and demographic variables (gender and education) provide more comprehensive explanation about the factors that influence citizens' intention to adopt microfinance services.

\section{RESEARCH LIMITATIONS AND SUGGESTIONS FOR FUTURE RESEARCH :}

The target respondents for the current study were rural citizens who were not using microfinance services during the data collection. As the result, current study findings represent the perceptions of non-users of microfinance services that possibly could be distinct from the actual users' perceptions. Therefore, this study suggests future research that could addresses the behavioural factors of the actual users of microfinance services. The timing for data collection was also one of the challenges of this study as it overlapped with busy schedule for most of the rural citizens that include farming activities. Nevertheless, the response rate achieved $82 \%$ that was adequate for data analysis in this study. This study recommends further study that can improve the current response rate.

\section{REFERENCES :}

[1] Abu-Shanab, E. A. (2011). Education level as a technology adoption moderator. In Computer Research and Development (ICCRD), 2011 3rd International Conference on Computer Research and Development (Vol. 1, pp. 324-328). Shanghai, China, March 11-13, 2011: IEEE.

[2] Ajzen, I. (1991). The theory of planned behavior. Organizational Behaviour and Human Decision Processes, 50, 179-211. 
[3] Alliance for Financial Inclusion. (2016). Tanzania Narrows the Financial Inclusion Gender Gap a Case Study of Policy Change to Support Women ' S Financial Inclusion.

[4] Allred, S. B., \& Ross-Davis, A. (2011). The drop-off and pick-up method: An approach to reduce nonresponse bias in natural resource surveys. Small-Scale Forestry, 10(3), 305-318.

[5] Alqasa, K. M. (2014). The impact of students' attitude and subjective norm on the behavioural intention to use services of banking system. Int. J. Business Information Systems, 15(1), 105-122.

[6] Alsmady, A. A., Rahman, R. A., \& Muhammad, A. D. (2014). Ethical Responsibility and Applicability of Islamic Micro-Investment Model ( IMIM ) in Jordan. Middle-East Journal of Scientific Research, 22(5), 743-751.

[7] Amin, H., Rahma, A. R. A., \& Razak, D. A. (2014). Willingness to $\mathrm{Be}$ a Partner in Musharakah Mutanaqisah Home Financing: Empirical Investigation of Psychological Factors. Jurnal Pengurusan, 40, 69-81.

[8] Ashraf, M. A. (2014). Willingness behavior of the rural poor to participate in MFIs : Evidence from Bangladesh. European Journal of Business and Management, 6(23), 103-115.

[9] Awang, Z. (2015). SEM Made Simple: A Gentle Approach to Learning Structural Equation Modeling. Selangor: MPWS Rich Publication Sdn. Bhd.

[10] Bagozzi, R. P., Baumgartner, H., \& Yi, Y. (1992). State versus action orientation on the TRA action: An application of coupon usage. Journal of Consumer Research, 18(4), 505-518.

[11] Bank of Tanzania. (2014). Directorate of Banking Supervision Annual Report. Dar es salaam. Retrieved from http://www.bot.go.tz/ Banking Supervision/Reports/DBS ANNUAL
[12] Chen, Y., Yan, X., Fan, W., \& Gordon, M. (2015). Computers in Human Behavior The joint moderating role of trust propensity and gender on consumers' online shopping behavior. Computers in Human Behavior, 43, 272-283.

[13] Chogo, P. J., \& Sedoyeka, E. (2015). Exploring Factors Affecting Mobile Money Adoption in Tanzania. International Journal of Computing and ICT Research, 8(2), 53-64.

[14] Chuah, F., Ting, H., de Run, E. C., \& Cheah, J.-H. (2016). Reconsidering What Entrepreneurial Intention Implies: The Evidence from Malaysian University Students. International Journal of Business and Social Science, 7(9), 85-98.

[15] Claar, C. L., \& Johnson, J. (2010). Analyzing the adoption of computer security utilizing the health belief model. Issues in Information Systems, 11(1), 286291.

[16] Davis, F. D. (1989). Perceived Ease of Use, and User Acceptance of Information Technology. MIS Quarterly, 13(3), 319340.

[17] Deng, Z., Mo, X., \& Liu, S. (2013). Comparison of the middle-aged and older users ' adoption of mobile health services in China. International Journal of Medical Informatics, 83(3), 210-224.

[18] Fishbein, M., \& Ajzen, I. (1975). Belief, Attitude, Intention and Behaviour: An Introduction to theory and Research. Amherst: Addison- Wesley. Retrieved from philpapers.org/rec/FISBAI

[19] Fornell, C., \& Larcker, F. D. (1981). Evaluating structural equation models with unobservable variables and measurement error. Journal of Marketing Research, 18(1), 39-50.

[20] FSDT. (2014). Promoting financial inclusion in Tanzania. Dar es salaam. Retrieved from http://www.fsdt.or.tz/wpcontent/uploads/2 016/05/FSDT-Our-Work2013-2014-Full-Report.pdf 
[21] Gibler, K., \& Nelson, S. (2003). Consumer behavior applications to real estate education. Journal of Real Estate Practice and Education, 6(1), 63-83.

[22] Gopi, M., \& Ramayah, T. (2007). Applicability of theory of planned behavior in predicting intention to trade online. International Journal of Emerging Markets, 2(4), 348-360.

[23] Heikal, M., \& Khaddafi, M. (2014). The Intention to Pay Zakat Commercial: An Application of Revised Theory of Planned Behavior. Journal of Economics and Behavioral Studies, 6(9), 727-734.

[24] Hooft, E., Born, M., Taris, T., \& Flier, H. (2006). Ethnic and Gender Differences in Applicants' Decision-Making Processes: An Application of the Theory of Reasoned Action. International Journal of Selection and Assessment, 14(2), 156-166.

[25] Humaidi, N., \& Balakrishnan, V. (2015). Leadership Styles and Information Security Compliance Behavior: The Mediator Effect of Information Security Awareness. International Journal of Information and Education Technology, 5(4), 311-318.

[26] Jebarajakirthy, C., \& Lobo, A. C. (2014). War affected youth as consumers of microcredit: An application and extension of the Theory of Planned Behaviour. Journal of Retailing and Consumer Services, 21(3), 239-248.

[27] Kim, D. J., Ferrin, D. L., \& Rao, R. H. (2008). A Trust-Based Consumer Decision Model in Electronic Commerce: The Role of Trust, Risk, and Their Antecedents. Decision Support Systems, 44(2), 544-564.

[28] Kline, R. B. (2011). Principles and Practice of Structural Equation Modeling. (D. T. Little, Ed.) (3rd ed.). New York: The Guilford Press.

[29] Lee, M. (2009). Predicting and explaining the adoption of online trading: An empirical study in Taiwan. Decision Support Systems, 47(2), 133-142.
[30] Maiyaki, A. A. (2013). Moderating effect of individualism/collectivism on the association between service quality, corporate reputation, perceived value and consumer behavioural intention. Journal of Marketing \& Management, 4(1), 1-20.

[31] Mbawuni, J., \& Nimako, S. G. (2015). Predicting Clients' Intentions to Acquire Credit Facilities in Ghanaian Financial Market. International Journal of Economics and Finance, 7(2), 63-77.

[32] Ministry of Agriculture Food Security and Cooperatives. (2015). Statement by Minister of Agriculture Food Security and Cooperatives Hon. Stephen M. Wasira (MP) During the IFAD Roundtable Workshop-Tanzania Country Programme Evaluation (CPE). Dar es salaam: United Republic of Tanzania. Retrieved from www.ifad.org/documents/10180/45751371af2d-4196-96d4-0f8753b044b6

[33] Mishra, S. (2014). Adoption of Mcommerce in India: Applying Theory of Planned Behaviour Model. Journal of Internet Banking and Commerce, 19(1), 117.

[34] Nasri, W. (2011). Factors Influencing the Adoption of Internet Banking in Tunisia. International Journal of Business and Management, 6(8), 143-160.

[35] National Bureau of Statistics. (2013). Statistical abstract 2013. Dar es salaam. Retrieved from http://www.nbs.go.tz/nbs/ Statistical Abstract/Statistical Abstract Report 2013.pdf

[36] National Bureau of Statistics. (2014). Basic Demographic and Socio-Economic Profile. Dar es salaam. Retrieved from http://www.tanzani a.go.tz/egov_uploads/documents/Descriptiv e_tables_Tanzania_Mainland_sw.pdf

[37] Ng, T., \& Feldman, D. (2009). How Broadly Does Education Contribute to Job Performance? Personnel Psychology, 62, 89-134.

[38] Okibo, B. W., \& Makanga, N. (2014). 
Effects of micro finance institutions on poverty reduction in Kenya. International Journal of Current Research and Academic Review, 2(2), 76-95.

[39] Otieno, O. C., Liyala, S., Odongo, B. C., \& Abeka, S. (2016). Theory of Reasoned Action as an Underpinning to Technological Innovation Adoption Studies. World Journal of Computer Application and Technology, 4(1), 1-7.

[40] Park, J., Yang, S., \& Lehto, X. (2007). Adoption of mobile technologies for chinese consumers. Journal of Electronic Commerce Research, 8(3), 196-206.

[41] Porter, C. E., \& Donthu, N. (2006). Using the technology acceptance model to explain how attitudes determine Internet usage: The role of perceived access barriers and demographics. Journal of Business Research, 59(9), 999-1007.

[42] Putit, L., \& Johan, Z. J. (2015). C onsumers "Acceptance of Halal" Credit Card Services: An Empirical Analysis. Journal of Emerging Economies and Islamic Research, 3(1), 1-9.

[43] Ross, T. P., Ross, L. T., Rahman, A., \& Cataldo, S. (2010). The Bicycle Helmet Attitudes Scale: Using Among Undergraduates. Journal of American College Health, 59(1), 29-36.

[44] Rouibah, K., Ramayah, T., \& May, O. S. (2011). Modeling User Acceptance of Internet Banking in Malaysia: a Partial Least Square ( Pls) Approach. In Eadoption and socio-economic impacts: Emerging infrastructural effects (pp. 1-23). Pennsylvania, USA: IGI Global.

[45] Rubambey, G. C. (2005). Policy, Regulatory and Supervisory Environment for Microfinance in Tanzania. Bank of Tanzania. Dar es salaam. Retrieved from http://www.arabic.microfinancegateway.org /sites/default/files /mfg-e n-paper-policyregulatory-and-supervisory-environmentfor-microfinance-in-tanzania-2005.pdf

[46] Rugumamu, C. (2014). Empowering smallholder rice farmers in Tanzania to increase productivity for promoting food security in Eastern and Southern Africa. Agriculture \& Food Security, 3(1), 7.

[47] Sayid, O., \& Echchabi, A. (2013). Attitude of Somali Customers towards Mobile Banking Services: The Case of Zaad and Sahal Services, II(3), 9-16.

[48] Schumacker, R. E., \& Loamx, R. G. (2010). A Beginners Guide to Structural Equation Modeling (3rd ed.). New York: Taylor \& Francis Group.

[49] Shanmugam, A., Savarimuthu, M., \& Wen, T. (2014). Factors Affecting Malaysian Behavioral Intention to Use Mobile Banking With Mediating Effects of Attitude. Academic Research International, 5(2), 236-253.

[50] Siddik, N. A., Sun, G., Yanjuan, C. U. I., \& Kabiraj, S. (2014). Financial Inclusion through Mobile Banking: A Case. Journal of Applied Finance \& Banking, 4(6), 109136.

[51] Simbolon, S. (2015). Application of Theory of Reasoned Action in Predicting the Consumer Behaviour to Buy the Toyota Avanza Veloz at Pt. Putera Auto Perkasa Medan. Journal of Asian Scientific Research, 5(7), 357-372.

[52] Tanadi, T., Samadi, B., \& Gharleghi, B. (2015). The Impact of Perceived Risks and Perceived Benefits to Improve an Online Intention among Generation-Y in Malaysia. Asian Social Science, 11(26), 226-238.

[53] Tsordia, C., \& Papadimitriou, D. (2015). The Role of Theory of Planned Behavior on Entrepreneurial Intention of Greek Business Students. International Journal of Synergy and Research, 4(1), 23-37.

[54] Venkatesh, V., Morris, M., Davis, G., \& Davis, F. (2003). User acceptance of information technology: toward a unified view. MIS Quarterly, 27(3), 425-478.

[55] Wong, K., Teo, T., \& Russo, S. (2012). Influence of gender and computer teaching 
efficacy on computer acceptance among Malaysian student teachers: An extended technology acceptance model. Australasian Journal of Educational Technology, 28(7), 1190-1207.

[56] Wu, I., Li, J., \& Fu, C. (2011). The adoption of mobile healthcare by hospital's professionals: An integrative perspective. Decision Support Systems, 51(3), 587-596.

[57] Yang, C., Hsu, Y., \& Tan, S. (2010). Predicting the Determinants of Users' Intentions for Using YouTube to Share Video: Moderating Gender Effects. Cyberpsychology, Behavior, and Social Networking, 13(2).

[58] Zohir, S., \& Matin, I. (2004). Wider impacts of microfinance institutions: Issues and concepts. Journal of International Development, 16(3), 301-330. 